УДК: 35.08 (477)

DOI: https://doi.org/10.32689/2618-0065-2020-1(3)-185-195

Федотова Тетяна Анатоліївна, доцент, кандидат економічних наук, доцент, Дніпровський національний університет ім. О. Гончара; 49010 Дніпро, пр. Гагаріна, 72; тел.: +380507322102; e-mail: feduy@ukr.net.

ORCID: 0000-0002-9529-3429

\title{
КОНЦЕПТУАЛЬНІ ОСНОВИ ПІДГОТОВКИ УПРАВЛІНСЬКИХ КАДРІВ ДЕРЖАВНОЇ СЛУЖБИ
}

Анотація: Розглянута сучасна концепція категорії «управлінські кадри» та відображено основні особливості їх діяльності. Зазначено необхідність відбору для державної служби потенційно здібних управлінців, які мають відповідний талант і бажання, для підготовки їх до ефективної роботи в умовах інноваційно-орієнтованого розвитку, що може і повинна виконувати система управлінської освіти. Формування інноваційноорієнтованої вітчизняної системи підготовки управлінських кадрів $\epsilon$ невідкладною потребою сучасного суспільства. Важливою і невід'ємною складовою частиною цієї системи $є$ вищі навчальні заклади, які пропонують цикл курсів управлінського спрямування.

Визначено певні відмінності підготовки управлінського персоналу для сфери державного управління від традиційної академічної освіти.

Зазначено, що багато сучасних державних службовців, які займають керівні посади, не отримали спеціальної підготовки у сфері управління. Тому, навчанню вже сформованого керівного складу необхідно надавати особливе значення, оскільки розвиток інноваційно-орієнтованого управління державою неможливий без керівників, що володіють сучасними знаннями, навичками ефективної розробки і ухвалення управлінських рішень.

Безперервне професійне навчання управлінських кадрів повинне стати одним 3 пріоритетних напрямів кадрової політики і здійснюватися 3 метою підвищення ефективності і якості праці державного службовця, постійного зростання рівня його професійності, оволодіння новими методами управління, i навичками роботи в умовах інноваційно-орієнтованого розвитку країни.

Особливе місце в системі професійної освіти має бути відведено зміцненню зв'язків освітніх закладів і з державними органами. Визначено основні завдання на рішення яких має бути спрямоване навчання управлінського персоналу державної служби, а також базові принципи системи навчання керівних кадрів органів державного управління.

Для підвищення іноваційності освітньої системи досить актуальною на сьогодні $є$ проблема пошуку та підготовки викладачів високого рівня, підвищення кваліфікації професорсько-викладацького складу. Освітні 
заклади повинні здійснювати свою діяльність в умовах, коли вимоги до професіоналізму і компетентності управлінців усіх рівнів державного управління постійно змінюються.

Ключові слова: державна служба, управлінські кадри, підготовка кадрів, управлінська еліта, керівні кадри, державне управління.

Fedotova Tatiana Anatoliivna, Associate Professor, Candidate of Economic Sciences, Associate Professor; Oles Honchar Dnipro National University; 49010 Dnipro, 72 Gagarin Ave.; tel.; +380507322102; e-mail: feduy@ukr.net

ORCID: 0000-0002-9529-3429

\section{CONCEPTUAL BASES OF PUBLIC SERVICE MANAGEMENT TRAINING}

Abstract: The modern concept of the category "management personnel" is considered and the main features of their activity are reflected. The necessity of selection for the civil service of potentially capable managers, who have the appropriate talent and desire, to prepare them for effective work in the conditions of innovation-oriented development, which can and should be fulfilled by the system of management education, is stated. Formation of an innovation-oriented domestic system of management training is an urgent need of modern society. An important and integral part of this system is the higher education institutions that offer a series of management courses.

Some differences of management personnel training in the sphere of public administration from traditional academic education are identified.

It is noted that many modern civil servants holding managerial positions have not received specific training in management. Therefore, the training of the already formed leadership should be given special importance, since the development of innovatively-oriented government is impossible without leaders who have the modern knowledge, skills to effectively develop and make management decisions.

Continuous professional training of managerial staff should become one of the priority areas of personnel policy and should be carried out in order to improve the efficiency and quality of work of a civil servant, to constantly increase the level of his professionalism, mastering new methods of management, and working skills in the conditions of innovation-oriented development of the country.

A special place in the system of vocational education should be given to strengthening the relations between educational institutions and with state bodies. The main tasks for the decision of which should be directed training of the administrative staff of the civil service, as well as the basic principles of the system of training of management personnel of public administration bodies. 
To increase the innovativeness of the education system, the problem of finding and training high-level teachers and improving the skills of the teaching staff is quite relevant today. Educational institutions should operate in a context where requirements for the professionalism and competence of managers at all levels of government are constantly changing.

Key words: public service, managerial staff, training talents, managerial elite, managerial staff, public administration.

Постановка проблеми. Зміни, які відбулися впродовж останніх десятиліть в національному середовищі, зумовили необхідність комплексного реформування сектора державної служби, його адаптації до інноваційно-орієнтованих умов господарювання, вдосконалення системи державного управління. Тривалість цих процесів і їх успішність значною мірою залежать від того, наскільки ефективними будуть рішення невідкладних проблем у сфері державного управління. Дані аспекти обумовлюють особливо високі вимоги до професійної компетенції управлінського персоналу в цьому секторі.

Специфіка посилення ролі державних службовців обумовлює об'єктивну необхідність розробки послідовної політики підготовки управлінського персоналу, визначення мети, завдань і функцій механізму іiі здійснення. Це вимагає подальшого, як теоретичного обгрунтування, так i методичного забезпечення. Актуальність відміченого комплексу проблем, їх теоретична i практична значущість,, а також недостатня розробленість зумовили вибір тематики дослідження.

Аналіз останніх публікацій за проблематикою. Питання кадрового забезпечення та специфічності управлінської праці зокрема розглядалися такими вченими як Р. Акофф, І. Ансофф, Г. Беккер, П. Друкер, Г. Мінцберг, Е. Тофлер, А. Чандлер, Т. Шульц. Серед українських вчених, які приділяли увагу даному питанню, слід зазаначити таких, як С. І. Бандур, В. Ф. Беседін, Д. П. Богиня, І. К. Бондар, А. С. Гальчинський, В. М. Геєць, М. І. Долішній, А. М. Колот, Ю. М. Краснов, Е. М. Лібанова, І. І. Лукінов, Е. Г.Панченка М. Г. Чумаченко, А. А. Чухно та інші. Як напрямок дослідження роль управлінської еліти в суспільстві та економіці розвитку розглядали такі російські дослідники як М. Афанасьєв, Г. Ашин, О. Гаман-Голутвінова, С. Глазьєв, Ю. Левада, Е. Охотський, В. Ледяев, Т. Заславська та ін.

Безпосередньо увагу питанням підготовки державних службовців приділено у працях таких вітчизняних вчених за різними напрямами: щодо системи підготовки - Т. Крушельницька та С. Пригородова [1], Серьогін С. [2], в контексті професіоналізації державної служби [3] - колектив авторів та I. Гусак [4], щодо керівних посад - Стельмащук М.С. [5], в аспекті дослідження закордонного досвіду - Артеменко Н. [6], Богданова Н. [7], Гриненко В. [8], Кіцак Т. [9], Корнута Л. [10], Титаренко Л. [11] та ін. 
За методологічну основу дослідження взяті діалектичні методи наукового пізнання, системний підхід до визначення ролі підготовки управлінського персоналу в сукупності процесів державного творення.

Формулювання цілей (мети) статті. Метою статті є обгрунтування основних напрямів підготовки управлінських кадрів в умовах інноваційноорієнтованого розвитку держави.

Виклад основного матеріалу дослідження. Проблема людського чинника в управлінні пов'язана 3 прагненням людини до певної мети і іï досягнення. В зв'язку 3 цим важливим є з'ясування основних складових діяльності управлінця: мотиву, мети, планування діяльності, опрацювання поточної інформації, оперативного ухвалення рішень і дії, перевірки результатів і корекції дій.

Сучасна концепція категорії «управлінські кадри» відображає основні особливості їх діяльності, а саме:

керівників;

- потреба високої кваліфікації, ініціативності і самостійності

- особова сформованість 3 чітко певною метою, прагненнями i переконаннями;

- уміння пристосовувати свій стиль керівництва і підходи до управління до різноманітних умов і мікроклімату в організації [12, с. 57].

Вказані особливості діяльності сучасних управлінських працівників ініціюють виконання основних загальних функцій державного управління в процесі щоденної роботи.

Від таких якостей управлінських працівників, як професійна компетентність, уміння приймати ефективні рішення і забезпечувати їх виконання, оволодіння сучасними технологіями, прагнення до самовдосконалення і службового зростання залежать динамізм і успішність розвитку сфери державного управління підприємства. Нові реалії вимагають від управлінських працівників усіх рівнів уміння знаходити нестандартні рішення, відстоювати свої погляди, бути гнучкими, комунікабельними, висококваліфікованими фахівцями. Саме таких фахівців повинні готувати навчальні заклади, оскільки усі підгалузі державного управління відчувають велику потребу в кваліфікованих управлінських працівниках.

Таким чином, перед державою постають проблеми відбору потенційно здібних управлінців, які мають відповідний талант і бажання, для підготовки їх до ефективної роботи в умовах інноваційно-орієнтованого розвитку.

Цю функцію може і повинна взяти на себе система управлінської освіти. Треба підкреслити, що головною функцією такої системи повинна стати саме грунтовна підготовка управлінців. Це дозволить реалізувати концептуальну одноманітність в розумінні цілей і завдань навчання, досягти синергетичного ефекту, коли результати від вивчення окремих організаційноуправлінських дисциплін, об'єднуючись, призводять до якісно нової системи 
знань відносно теорії і практики управління, стають ресурсами подальшого економічного зростання країни.

Формування інноваційно-орієнтованої вітчизняної системи підготовки управлінських кадрів $\epsilon$ невідкладною потребою сучасного суспільства. Важливою і невід'ємною складовою частиною цієї системи є вищі навчальні заклади, які пропонують цикл курсів управлінського спрямування.

Управлінська діяльність завжди передбачає самодіяльність і творчість суб'єктів і об'єктів управління. Управлінські дії потребують розумного використання людських ресурсів в управлінні, а недбале відношення до них може спричинити ескалацію (загострення) конфліктів, плинність кадрів і т. д.

Кінцевою метою підготовки управлінських кадрів повинне стати формування стратегічного мислення, здібності мислити творчо і можливості працювати в ширшій перспективі.

Особливості сучасної організації підготовки управлінського персоналу для сфери державного управління зумовлені тим, що така підготовка має певні відмінності від традиційної академічної освіти. Оскільки система підготовки управлінського персоналу - це не просто отримання нових знань, знайомство 3 новими інформаційно-технологічними можливостями і рішеннями, це, в першу чергу, створення стійкої системи управлінської компетенції. Ця система складається 3 установок і цінностей, які 3 урахуванням сучасних теоретичних концепцій управління, практичних умінь i навичок, сприятимуть ефективності господарювання за рахунок оптимуму прийнятих управлінських рішень, зростанню продуктивності управлінської праці, досягненню критеріїв стійкого розвитку держави.

Слід зазначити, що багато сучасних державних службовців, які займають керівні посади, не отримали спеціальної підготовки у сфері управління, і відповідно, ведуть управлінську діяльність, керуючись інтуїцією і методом проб, без використання сучасних знань у сфері менеджменту [5]. Тому, навчанню вже сформованого керівного складу необхідно надавати особливе значення, оскільки розвиток інноваційноорієнтованого управління державою неможливий без керівників, що володіють сучасними знаннями, навичками ефективної розробки і ухвалення управлінських рішень.

Безперервне професійне навчання управлінських кадрів повинне стати одним 3 пріоритетних напрямів кадрової політики і здійснюватися 3 метою підвищення ефективності і якості праці державного службовця, постійного зростання рівня його професійності, оволодіння новими методами управління, i навичками роботи в умовах інноваційно-орієнтованого розвитку країни.

Впродовж усієї трудової діяльності державних службовців відповідно до встановленої для кожної категорії періодичності повинне здійснюватися підвищення кваліфікації з метою оновлення теоретичних і практичних знань, 
умінь і навичок керівників і фахівців відповідно до постійно зростаючих вимог державних освітніх стандартів і особливостей державотворення.

Виходячи 3 цілей, цей процес повинен включати такі види навчання:

- короткострокове тематичне навчання 3 питань конкретного виду державного управління (впровадження нової технології);

- тематичні і проблемні семінари або вебінари 3 науково-технічних, технологічних, соціально-економічних і інших питань;

- довготривале навчання для поглибленого вивчення актуальних питань за профілем професійної діяльності;

- стажування для закріплення професійних знань, отриманих в результаті теоретичної підготовки, для вивчення досвіду i для реалізації можливості переходу на вищі посади;

- професійна підготовка, метою якої $є$ отримання керівниками i службовцями додаткових знань, умінь i навичок згідно програм, які передбачають вивчення окремих предметів, необхідних для виконання нової професійної діяльності.

Наступний крок в системі безперервного професійного навчання щорічне навчання управлінського персоналу державної служби 3 метою ознайомлення його з новими комп'ютерними програмами і прогресивними технологіями, ефективними методами аналізу і управління і т. п.

Серйозною проблемою функціонування системи підготовки управлінських кадрів державної служби слід виділити наявний розрив між знаннями i навичками отриманого навчання управлінців i практикою управління, що реалізується вищим керівництвом [13]. Важливо, щоб керівництво державних органів не лише вирішувало питання, пов'язані 3 навчанням підлеглих кадрів, але i розробляло необхідні заходи по використанню результатів навчання у своїй практичній діяльності для отримання віддачі від витрачених на навчання ресурсів.

Форма підготовки управлінських кадрів визначається, виходячи 3 мети і змісту програм діяльності: 3 відривом від роботи (очна), без відриву від роботи (заочна, вечірня), з частковим відривом від роботи (очно-заочна), у формі самоосвіти, екстернатура, аспірантура.

Підготовка зводиться до розвитку навичок і умінь, необхідних управлінцям для ефективного виконання своїх посадових обов'язків в майбутньому. На практиці систематичні програми підготовки найчастіше використовують для того, щоб готувати керівників до просування по службі [14].

В цілому навчання управлінського персоналу державної служби має бути спрямоване на рішення наступних завдань:

- підготовка до ефективного вирішення нових завдань, які буде необхідно виконувати в найближчій перспективі; 
- поглиблення знань у сфері менеджменту і розвиток управлінських навичок, необхідних для ефективного практичного застосування при рішенні щоденних завдань;

- переосмислення старого досвіду, формування нових підходів до роботи, нових установок, здатних забезпечити успіх в мінливих умовах;

- розвиток у керівного складу установок, сприяючих підвищенню: індивідуальної ефективності праці, продуктивнішій взаємодії з підлеглими і успішному досягненню цілей державного органу.

Система навчання керівних кадрів органів державного управління повинна базуватися на наступних принципах:

1. Зміст навчання повинен відповідати функціональним цілям державного органу. Практика показує, що застарілий обсяг знань, якими володіють керівники, не дозволяє ефективно вирішувати складні питання в умовах, що постійно змінюються.

2. Зміст навчання управлінського персоналу має бути тісно пов'язаний 3 характером функціонування і структурою їх державного органу. Сьогодні визначають набір вимог до керівників, які використовуються при відборі і призначенні на посаду на основі їх "управлінських компетенцій". Ці вимоги мають бути тісно пов'язані із забезпеченням постійного навчання, оскільки розвиток управлінських компетенцій веде до зростання якості управління i рівня конкурентоспроможності країни.

3. Управлінський персонал повинен уміти вирішувати не лише поточні проблеми, але і розуміти основи таких дисциплін, як економіка, менеджмент, психологія, соціологія, фінанси і маркетинг. Досвід управління свідчить, що ефективність більшою мірою визначається не структурою, технологіями, та ін., а організаційною культурою їх керівників і менеджерів, їх здатністю сформувати у колективі бажання бути першими, здатністю мобілізувати зусилля кожного працівника на досягнення кінцевої мети діяльності державного органу і професійно поставлених цілей.

4. Спрямованість управлінської ланки державної служби на постійне оновлення своїх знань і компетенцій.

Необхідність докорінного поліпшення якості кадрового потенціалу, забезпечення його ефективного професійного розвитку зумовлена потребою у висококваліфікованих кадрах, ерудованих компетентних управлінців 3 інноваційним мисленням, здатних до відповідального прийняття управлінських рішень [15, с. 225]. Сучасний державний управлінець повинен бути фахівцем, готовим до роботи в реальних умовах державного органу, регіону і країни в цілому.

Для підвищення іноваційності освітньої системи досить актуальною на сьогодні є проблема пошуку та підготовки викладачів високого рівня, підвищення кваліфікації професорсько-викладацького складу, рішення якої потребує значного фінансування і кадрового реформування галузі освіти. Система освіти побудована таким чином, що багато викладачів не мають 
часу на практичну діяльність. У зв'язку з цим має місце нестача викладачівпрактиків, які поєднують діяльність в сфері державного управління 3 викладацькою роботою. В результаті студенти отримують в більшій мірі теоретичні знання, які не підкріплені прикладами 3 практики державотворення та досвідом їх реалізації в реальній ситуації.

У вирішенні даної проблеми особлива роль відводиться організації та проведенню підвищення кваліфікації та професійної перепідготовки викладачів в напрямку вдосконалення їх предметної області знань, засвоєння нових технологій, впровадження в освітній процес інноваційних методів навчання. Крім того, необхідна комплексна підготовка 3 педагогіки, психології, етики, права, менеджменту та ін.

Отже, реалізація цього підходу повинна відбуватися в двох основних напрямках:

- навчання викладацькій майстерності фахівців-практиків: організація шкіл викладацької майстерності з упором на активні та інтерактивні методи спілкування з фахівцями;

- отримання викладачами спеціальних професійних знань і практичного досвіду в сфері окремих дисциплін і спеціалізації: стажування у відповідних органах для отримання практичних знань і досвіду в області викладацької спеціалізації.

Особливе місце в системі професійної освіти має бути відведено зміцненню зв'язків освітніх закладів і 3 державними органами через реалізацію спільних консультаційно-освітніх програм, стажувань, виробничих практик, залучення успішних управлінських кадрів до викладацького процесу. На базі освітніх закладів перспективною $є$ організація ділових центрів в рамках предметної діяльності, в які доцільно залучати управителів-практиків.

Ці заходи можна вважати програмою мінімум. Проте, програмою максимум в рішенні даного питання в перспективі повинна стати можливість викладацького складу працювати за сумісництвом в рамках своєї предметної діяльності або, хоча би залучатися до вирішення практичних завдань на рівні державного управління, розробки на замовлення науково-практичної теми, участі в розробці, моніторингу та коригування різних регіональних та національних програм державного розвитку і т.п.

Другим важливим напрямком підвищення іноваційності освітньої системи слід позначити збалансованість формування управлінського потенціалу з кон'юнктурними коливаннями ринку праці.

Ринкова потреба в управлінських кадрах має тенденцію до постійних змін кількісних і структурних компонент. Тому освітні заклади повинні здійснювати свою діяльність в умовах, коли вимоги до професіоналізму i компетентності управлінців усіх рівнів державного управління постійно змінюються. На даний момент розвитку особливу затребуваність мають державні управителі, які мають додаткову спеціальність в сферах діяльності 
конкретних об'єктів національної економіки і досвід практичної роботи. У більшості випадків молодь після закінчення навчальних закладів незатребувана через відсутність досвіду роботи, а також через галузеву або територіальну несумісність.

Таким чином, сучасна концепція сфери освіти повинна стимулювати якісно нові зміни в підготовці висококваліфікованих фахівців сфери державного управління, націлювати їх на подальший професійне розвиток протягом життя і створювати оптимальні умови для реалізації їх потенціалу розвитку інтелектуальної праці. В широкому масштабі інноваційний підхід в освітньому процесі призведе до зростання національного освітнього потенціалу країни і загальної вартості людського капіталу.

Висновки і перспективи подальших досліджень. У багатьох країнах пострадянського простору доки ще не сформувалося остаточне усвідомлення того, що серед головних чинників, які забезпечують ефективне державне управління в ринкових умовах, $\epsilon$ реформування структури та системи державного управління, істотне підвищення соціальної і функціональної компетентності управлінських кадрів, можливість своєчасно адаптувати стратегію управління до швидкомінливих умов зовнішнього середовища, здатність надихати підлеглих, уміння розпізнавати і розвивати творчий потенціал державних службовців, власна ініціативність і гнучкість в ухваленні рішень. Оскільки процеси європейської інтеграції охоплюють все більше сфер життєдіяльності, провідну роль в цих сферах повинна грати управлінська освіта. Стратегічною метою підготовки управлінських кадрів для сфери державного управління повинне стати формування управлінського потенціалу, здатного забезпечити стійкий іноваційно-орієнтирований розвиток усіх галузей і сфер національної економіки.

\section{Лimepamypa:}

1. Крушельницька Т., Пригородова С. Удосконалення системи професійного навчання державних службовців: інноваційно-інформаційний аспект // Вісник Національної академії державного управління при Президентові України. - 2010. - № 4. C. 49-57.

2. Серьогін С. Реформування професійного навчання державних службовців в Україні: проблеми та перспективи: монографія / Серьогін, Є. Бородін, Н. Липовська та ін. - Київ, 2013. - 112 с.

3. Підготовка магістрів державної служби у вищих навчальних закладах України в контексті професіоналізації державної служби в Україні: організацій- ний аспект / Т. П. Крушельницька, Р. А. Науменко, Л. М. Гогіна, С. А. Пригородова // Вісн. НАДУ. - 2009. № 2. - С. 49-69.

4. Гусак I. Сучасний стан професіоналізації державних службовців в Україні // Збірник наукових праць: Ефективність державного управління. - 2012. - Вип. 31. - С. $367-$ 373.

5. Стельмащук Л. С. Роль, завдання та функції керівника у посиленні відкритості державного органу влади // Державне управління: удосконалення та розвиток. - 2015. - № 9. - Режим доступу: http://www.dy.nayka.com.ua/?op=1\&z=886. 
6. Артеменко Н. Досвід Німеччини у професійному вдосконаленні державних службовців // Актуальні проблеми європейської та євроатлантичної інтеграції України: матеріали 4-ї регіон. наук.-практ. конф. / за заг. ред. Л. Прокопенка. - Дніпропетровськ ДРІДУ НАДУ, 2007. - С. 153-157.

7. Богданова Н. О. Зарубіжний досвід підготовки державно-управлінських кадрів та шляхи його адаптації в Україні // Політичні науки. Правознавство. - 2007. - Том 69. Випуск 56. - С. 97-104.

8. Гриненко В. Професійне навчання вищих керівних кадрів для державної служби в зарубіжних країнах // Вісник УАДУ. - 2005. - № 3. - С. 162-169.

9. Кіцак Т. Зарубіжні системи підготовки державних службовців // Ефективність державного управління: зб. наук. пр. / за заг. ред. В. С. Загорського, А. В. Ліпенцева. Львів: ЛРІДУ НАДУ. - 2009. - Вип. 18/19. - С. 495-593.

10. Корнута Л. Європейський досвід підготовки державних службовців для України: концепції та форми // Visegrad Journal on Human Rights. - 2016. - № 6 (2). - С. 81 86.

11. Титаренко Л. Підготовка управлінської еліти в Україні та зарубіжний досвід державного управління // збірник наук. праць Одеського регіонального інституту державного управління. - Вип. 1 (13). - Одеса: ОРІДУ Вісн. УАДУ. - 2003. - С. 206-216.

12. Чумаченко О. В. Проблемы определения категории «Управленческий персонал предприятия» и его классификация / О. В. Чумаченко, Т. С. Шульгина // Устойчивое развитие экономики. - 2011. - № 2. - С. 57-62.

13. Байдак Т. М. Целевая подготовка управленческих кадров // Актуальные проблемы государственного управления: Сборник научных трудов. - Х.: УАДУ, 2012. - № 2 (13): В 2-х ч. Ч.1. - С. 282 - 285.

14. Борщук М. Специфика формирования системы обучения управленческих кадров / М. Борщук, В. С. Загорский, А.В. Липенцев // Стратегия государственной кадровой политики - основа модернизации страны. - К., 2012. - С.230 - 233.

15. Голобор Н. Державна політика у сфері формування та розвитку освітньофахового потенціалу державно-управлінських кадрів в Україні // Вісник Національної академії державного управління. - 2013. - № 1. - С. 225-231.

\section{References:}

1. Krushel'nic'ka, T. \& Prigorodova, S. (2010) Udoskonalennja sistemi profesijnogo navchannja derzhavnih sluzhbovciv: innovacijno-informacijnij aspekt [Improvement of the system of professional training of public servants: innovative and informational aspect] // Visnik Nacional'noï akademiï derzhavnogo upravlinnja pri Prezidentovi Ukraïni - Bulletin of the National Academy of Public Administration under the President of Ukraine, 4, 49-57 [in Ukrainian].

2. Ser'ogin, S., Borodin, E., Lipovs'ka N. ta in (2013) Reformuvannja profesijnogo navchannja derzhavnih sluzhbovciv v Ukraïni: problemi ta perspektivi: monografija [Reforming the Professional Training of public Servants in Ukraine: Challenges and Prospects]. Kiïv [in Ukrainian].

3. Krushel'nic'ka, T. P. \& Naumenko, R. A. \& Gogina, L. M. \& Prigorodova, S. A. (2009) Pidgotovka magistriv derzhavnoï sluzhbi u vishhih navchal'nih zakladah Ukraïni $\mathrm{v}$ konteksti profesionalizaciï derzhavnoï sluzhbi v Ukraïni: organizacij- nij aspekt [Preparation of Masters of public Service in Higher Educational Institutions of Ukraine in the Context of Civil Service Professionalization in Ukraine: Organizational Aspect] Visn. NADU - Bulletin of UADU, 2, 49-69 [in Ukrainian].

4. Gusak, I. (2012) Suchasnij stan profesionalizaciï derzhavnih sluzhbovciv v Ukraïni [The Current State of Professionalization of public Servants in Ukraine] Zbirnik naukovih prac': 
Efektivnist' derzhavnogo upravlinnja - Collection of Scientific Papers: Efficiency of Public Administration, 31, 367-373 [in Ukrainian].

5. Stel'mashhuk, L. S. (2015) Rol', zavdannja ta funkciï kerivnika u posilenni vidkritosti derzhavnogo organu vladi [The role, tasks and functions of the leader in enhancing the openness of the state authority] Derzhavne upravlinnja: udoskonalennja ta rozvitok - Public administration: improvement and development, 9. Retrieved from http://www.dy.nayka.com.ua/?op=1\&z=886 [in Ukrainian].

6. Artemenko, N. (2007) Dosvid Nimechchini u profesijnomu vdoskonalenni derzhavnih sluzhbovciv [Experience of Germany in professional improvement of civil servants]. L. Prokopenko (Eds.), Aktual'ni problemi cvropejs'koï ta evroatlantichnoï integraciï Ukraïni: materiali 4-ï region. nauk.-prakt. konf.- Ukraine: materials 4th region. Research Practice Conf. (pp. 153-157). Dnipropetrovs'k DRIDU NADU [in Ukrainian].

7. Bogdanova, N. O. (2007) Zarubizhnij dosvid pidgotovki derzhavno-upravlins'kih kadriv ta shljahi jogo adaptaciï v Ukraïni [Foreign experience of training of state-administrative personnel and ways of its adaptation in Ukraine]. Politichni nauki. Pravoznavstvo - Political sciences. Science of law, 69, 56, 97-104 [in Ukrainian].

8. Grinenko, V. (2005) Profesijne navchannja vishhih kerivnih kadriv dlja derzhavnoï sluzhbi v zarubizhnih kraïnah [Professional training of senior executives for public service in foreign countries]. Visnik UADU - Bulletin of UADU, 3, 162-169 [in Ukrainian].

9. Kicak, T. (2009) Zarubizhni sistemi pidgotovki derzhavnih sluzhbovciv [Professional training of senior executives for public service in foreign countries].V. S. Zagors'kogo, A. V. Lipenceva (Eds.), Efektivnist' derzhavnogo upravlinnja: zb. nauk. pr. - The effectiveness of public administration. L'viv: LRIDU NADU, 18/19, 495-593 [in Ukrainian].

10. Kornuta, L. (2016) Evropejs'kij dosvid pidgotovki derzhavnih sluzhbovciv dlja Ukraïni: koncepcii ta formi [The European experience of training civil servants for Ukraine: concepts and forms]. Visegrad Journal on Human Rights - Visegrad Journal on Human Rights, 6 (2), 81-86 [in Ukrainian].

11. Titarenko, L. (2003) Pidgotovka upravlins'koï eliti v Ukraïni ta zarubizhnij dosvid derzhavnogo upravlinnja [Preparation of the administrative elite in Ukraine and foreign experience of public administration]. Zbirnik nauk. prac' Odes'kogo regional'nogo institutu derzhavnogo upravlinnja - Collection of Sciences. works of the Odessa Regional Institute of Public Administration, Odesa: ORIDU Visn. UADU, 1 (13), 206-216 [in Ukrainian].

12. Chumachenko, O. V. \& Shul'gina T. S. (2011) Problemy opredelenija kategorii «Upravlencheskij personal predprijatija» i ego klassifikacija [Problems of definition of the category "Management personnel of the enterprise" and its classification]. Ustojchivoe razvitie jekonomiki - Sustainable development of economy, 2, 57-62 [in Ukrainian].

13. Bajdak, T. M. (2012) Celevaja podgotovka upravlencheskih kadrov [Targeted training of managerial personnel]. Aktual'nye problemy gosudarstvennogo upravlenija: Sbornik nauchnyh trudov - Actual problems of public administration: Collection of scientific works. H.: UADU, 2 (13), V 2-h ch. Ch.1, 282 - 285 [in Ukrainian].

14. Borshhuk, M. \& Zagorskij, V. S. \& Lipencev A.V. (2012) Specifika formirovanija sistemy obuchenija upravlencheskih kadrov [Specificity of formation of the system of training of managerial personnel]. Ctrategija gosudarstvennoj kadrovoj politiki - osnova modernizacii strany - The strategy of state personnel policy - the basis of modernization of the country. K., 230-233 [in Ukrainian].

15. Golobor, N. (2013) Derzhavna politika u sferi formuvannja ta rozvitku osvitn'ofahovogo potencialu derzhavno-upravlins'kih kadriv v Ukraïni [State policy in the sphere of formation and development of educational and professional potential of state-administrative personnel in Ukraine]. Visnik Nacional'noï akademiï derzhavnogo upravlinnja - Bulletin of the National Academy of Public Administration, 1, 225-231 [in Ukrainian]. 